Asian J. Med. Biol. Res. 2015, 1 (2), 222-229; doi: 10.3329/ajmbr.v1i2.25615

\author{
Asian Journal of \\ Medical and Biological Research \\ ISSN 2411-4472 (Print) 2412-5571 (Online) \\ www.ebupress.com/journal/ajmbr
}

\title{
Article \\ Effects of long-term mineral fertilization and manuring on rice-rice cropping pattern in sub-tropical floodplain soil
}

\author{
Bornali Mostofa $^{{ }^{*}}$, Md. Zahir Raihan ${ }^{1}$, Mohammad Forhad Hossain ${ }^{1}$, Taneya Farhana ${ }^{2}$, Md. Mukul Mia ${ }^{3}$ and \\ Md. Abdul Kader ${ }^{1}$ \\ ${ }^{1}$ Department of Soil Science, Bangladesh Agricultural University, Mymensingh-2202, Bangladesh \\ ${ }^{2}$ Department of Entomology, Bangladesh Agricultural University, Mymensingh-2202, Bangladesh \\ ${ }^{3}$ Department of Genetics \& Plant Breeding, Bangladesh Agricultural University, Mymensingh-2202, \\ Bangladesh
}

*Corresponding author: Bornali Mostofa, Department of Soil Science, Bangladesh Agricultural University, Mymensingh-2202, Bangladesh. E-mail: bornali.mostofa@yahoo.com

Received: 20 July 2015/Accepted: 16 August 2015/ Published: 30 September 2015

\begin{abstract}
An experiment was carried out both boro season (February-June, 2013) and aman season (JulyDecember, 2013) in the permanent experimental field of the Department of Soil Science, Bangladesh Agricultural University (BAU), Mymensingh. The objectives of present research work were tosee the effects of long-term fertilization and manuring on soil fertility and yield of boro and aman rice in flood plain (Subtropical) soil (AericHaplaquepts). The experiment was laid out in a randomized complete block design with three replications. There were 10 treatment combinations viz, Control, N, NP, NK, NPK, NZn, NS, NSZn, NPKSZn and NPK+FYM. The results indicated that the yield contributing characters and yield of BRRI dhan28 (Boro rice) and BR11 (Aman rice) were significantly increased due to different treatments. For boro rice, the highest plant height $(\mathrm{cm}), 1000$-grain weight $(\mathrm{g})$, effective tiller hill ${ }^{-1}$ and biological yield $\left(\mathrm{t} \mathrm{ha}^{-1}\right)$ were found in NPKSZn treatment. The highest grain yield and straw yield of boro ricewere also observed in NPKSZn treatment. Grain yield was increased by $71 \%, 119 \%, 127 \%, 132 \%, 133 \%, 144 \%, 161 \%$ and $200 \%$ over Control in NZn, NS, NK, N, NP, NPK+FYM, NPK, NSZn and NPKSZn treatments, respectively. Straw yield was increased by $82 \%, 83 \%, 98 \%, 110 \%, 112 \%, 139 \%, 145 \%$, and $167 \%$ over Control in N, NP, NPK+FYM, NZn, NK, NPK, NSZn, NS and NPKSZn treatments, respectively. Again for aman rice, the highest number of unfilled grain panicle ${ }^{-1}$ grain yield $\left(\mathrm{t} \mathrm{ha}^{-1}\right)$ and harvest index $(\%)$ were recorded in NPKSZn treatment. Grain yield was increased by $79 \%, 85 \%, 87 \%, 97 \%, 116 \%, 117 \%, 159 \%$ and $165 \%$ over Control in NP, NZn, N, NPK, NPK+FYM, NK, NSZn, NS and NPKSZn treatments, respectively. Straw yield was increased by 119\%, $121 \%, 135 \%, 142 \%, 149 \%, 152 \%, 200 \%, 217 \%$, and $246 \%$ over Control in NP, N, NPK, NPK+FYM, NK, NZn, NPKSZn, NSZn and NS treatments, respectively.
\end{abstract}

Keywords: effects; mineral fertilization; manuring; rice-rice cropping pattern; floodplain soil

\section{Introduction}

Bangladesh is a densely populated agro-based country and rice (Oryza Sativa) is the staple food. Special emphasis is given on agriculture to meet the increasing demand for food. The cropping patterns of Bangladesh are mainly rice based. Rice is grown in all the three crop growing seasons. However, rice covers about $77 \%$ of total crop area in Bangladesh (BBS, 2011). Rice is grown in over 11.7 million hectares under the various schemes subject to irrigated, rainfed and deep water conditions in three distinct seasons namely aus, aman and boro (BBS, 2012). Among the three rice crops, aman rice covers about 38\% and boro rice covers about 55\% of total rice production (FAO, 2014). Combined application of organic manures and chemical fertilizers may 
provide higher benefit towards crop yield as compared to application of only chemical fertilizer in Bangladesh (Hasanet al., 2009).The farmers of our country are suggested to apply fertilizer and manure in all crops to increase yield in order to meet the demand of our ever increasing population. There are reports that the crops in our country have been stagnated or declined. But the reasons for this situation are not properly identified. As the fertilizers are chemical substances, they exert influence on physical, chemical and biological properties of soil as well as on the yield of crops. The use of adequate organic manures in combination with minimum chemical fertilizers proved it significant having long-term beneficial effect on soil properties and productivity of rice (Hasan, 2007). Information on effect of long-term intensive fertilization on yield and soil properties are limited Organic matter in soil is critical for better soil health and higher soil productivity. However, maintaining or improving soil organic carbon is difficult in arid and semi-arid regions in view of rapid oxidation of organic matter due to high temperature. Continuous application of organic manure is the only way to increase soil organic matter status (Katyal et al., 2001). Under these circumstances the present piece of research work was carried out during boro and aman season of 2013 to see the effects of long-term fertilization and manuring on soil fertility and yield of boro and aman rice in flood plain (Subtropical) soil. Many long-term experiments conducted in India showed increasing yield trends and accumulation of soil organic carbon and biological properties due to combined application of fertilizer and manures (Bhattacharyya et al. 2008, 2010, Vineela et al., 2008).

\section{Materials and Methods}

A study was carried out during the boro and aman season of 2013 in the permanent manurial experimental field of the Department of Soil Science at Bangladesh Agricultural University (BAU) farm, Mymensinghto find out the effects of long term intensive fertilization on yield of rice. Topographically the area was slightly undulating but the experimental plot was fairly leveled. It was above normal flood level but sometimes the plot remained flooded for short time by rainwater during monsoon season (Tables $1 \& 2$ ).

The experiment was laid out in randomized complete block design with three replications. The whole experimental field was divided into three blocks which represented three replications of the experiment. Each block was subdivided into ten unit plots for placement of ten treatments of the experiment. The total number of unit plots of the experiment was 30. The size of the unit plot was $11.5 \mathrm{~m} \mathrm{x} 6.5 \mathrm{~m}\left(74.75 \mathrm{~m}^{2}\right)$. The unit plots were separated from each other by earthen ails of $25 \mathrm{~cm}$ width and $10 \mathrm{~cm}$ high. There was $50 \mathrm{~cm}$ width and 10 $\mathrm{cm}$ deep irrigation channel between the blocks. The experiment comprised of ten different treatment combinations of manure and fertilizers namely, control, N, NP, NK, NPK, NZn, NS, NSZn, NPKSZn and $\mathrm{NPK}+\mathrm{FYM}$.

The doses and sources of different nutrients and FYM: used for boro and aman rice were as follows:

\begin{tabular}{|c|c|c|c|}
\hline \multirow{2}{*}{ Nutrient Element } & \multicolumn{2}{|c|}{ Dose $\left(\mathrm{kg} \mathrm{ha}^{-1)}\right.$} & \multirow{2}{*}{ Source(Fertilizers) } \\
\hline & Boro rice & Aman rice & \\
\hline $\mathrm{N}$ & 120 & 60 & Urea \\
\hline $\mathrm{P}$ & 14 & 4 & TSP \\
\hline $\mathrm{K}$ & 58 & 29 & MP \\
\hline $\mathrm{S}$ & 8 & 6 & Gypsum \\
\hline $\mathrm{Zn}$ & 1 & - & Zinc Oxide \\
\hline FYM & 5000 & - & Decomposed Cowdung \\
\hline
\end{tabular}

Treatments and fertilizer doses were revised as per the crop requirements since boro 2013 from the below described previous treatments. The major change was the update of fertilizer recommendation as per FRG (Fertilizer Recommendation Guide) 2012 and inclusion of full doses (100\%) of N, P and K fertilizers in N $(50 \%)+$ FYM treatment (Table 3).

After initiation of the field experiment, rice (boro and aman) was normally grown 2 times in a year following rainfed and irrigated rice based cropping patterns. Usually, boro rice is planted in November-December and is harvested in June-July, and the growing season of aman ranges from mid-July to mid-December. Irrigation water from a deep tubewell was given to the plots. Forty six rice crops were harvested up to the end of 2002 of which 29 were high-yielding varieties and 17 are local varieties. The boro rice (cv. BRRI dhan28) under study was ranked 67 and aman rice (cv. BR11) was ranked 68 rice crops up to the end of 2013. These two varieties have been developed by the Bangladesh Rice Research Institute (BRRI), Gazipur. The average yield of BRRI dhan28 is 5.5-6 t/ha. BR11 is a modern variety of rice and It gives an average yield of $6.5 \mathrm{t} / \mathrm{ha}$ under proper 
management (BRRI, 2010).Boro rice was harvested on 5 June 2013 and aman rice on 26 November and 5 December 2013 at maturity and threshed plot wise. Grain and straw obtained from each plot were dried and weighed carefully.

\section{Results}

3.1. Effect of long-term mineral fertilization and manuring on yield and yield contributing characters of boro rice

The plant height of boro rice (BRRI dhan28) in the experimental plot was significantly influenced due to different treatment combinations (Table 4). The highest plant height $(75.97 \mathrm{~cm})$ was recorded in NPKSZn treatment. Result revealed that plant height at NP and NPKSZn were statistically similar. Plant height in N, NP, NK, NPK, NS, NSZn, and NPK+FYM treatments were also statistically similar but superior to control and inferior than NPKSZn treatment. The lowest plant height $(67.48 \mathrm{~cm})$ was recorded in control.Analysis of variance of data showed that the effect of different treatment on 1000-grain weight (g) was not statistically significant (Table 4).The 1000-grain weight ranged from 20.67 to $25.67 \mathrm{~g}$. The 1000 grain weight followed the order of $\mathrm{NPKSZn}>\mathrm{NPK}>\mathrm{NP}=\mathrm{NS}>\mathrm{NSZn}=\mathrm{N}>\mathrm{Control}>\mathrm{NK}>\mathrm{NPK}+\mathrm{FYM}>\mathrm{NZn}$ (Table 4).Counting the filled grains per panicle a remarkable variation was observed between the treatments (Table 4). The highest number of filled grains (110) was found in NP treatment, whereas the lowest number (87) was found in control treatment. Results showed that filled grain panicle ${ }^{-1}$ in NS, NPKSZn, NZn and NPK+FYM were statistically similar. Again filled grain panicle $^{-1}$ in N, NK, NPK and NSZn were also statistically similar. In counting the unfilled grains per panicle, a remarkable variation was observed between the treatments (Table 4). The highest number of unfilled grains (14) was found in $\mathrm{N}$ treatment, whereas the lowest number (10) was in NPK treatment. The unfilled grain panicle ${ }^{-1}$ in N, NK and NSZn were statistically similar. It is evident from Table 4 that the number of tiller hill ${ }^{-1}$ was significantly affected by various treatment combinations (Table 4). The highest number of effective tillerhill ${ }^{-1}$ (9.00) was observed in NPKSZn treatment whereas the lowest (6.00) was recorded in control.The plants hill ${ }^{-1}$ due todifferent treatments ranked in the order of $\mathrm{NPKSZn}>\mathrm{NPK}+\mathrm{FYM}>\mathrm{NS}=\mathrm{NSZn}>\mathrm{NZn}>\mathrm{N}=\mathrm{NPK}>\mathrm{NP}=\mathrm{NK}>\mathrm{Con}$ trol (Table 4).The tiller hill ${ }^{-1}$ was statistically similar in NS, NSZn, NPKSZn and NPK+FYM treatments. Results showed that tiller hill $^{-1}$ were also statistically similar in N, NP, NK, NPK and NZn. There was also a significant effect of treatment on non-effective tiller. Non-effective tiller ranges between 0 in NP treatment and 0.67 in NS and NPKSZn treatments. The numbers of non-effective tiller in control, N, NK, NPK, NSZn, NZn and $\mathrm{NPK}+\mathrm{FYM}$ were statistically similarGrain yield of rice is the ultimate product of yield components which was significantly influenced by different treatment combinations (Table 4). The highest grain yield $\left(5.99 \mathrm{t} \mathrm{ha}^{-1}\right)$ was observed in NPKSZn treatment where the lowest $\left(2.00\right.$ tha $\left.^{-1}\right)$ was observed in control. Grain yield due to different treatment ranked in the order of NPKSZn $>N S Z n>N P K>N P K+F Y M>N P>N>N K>$ NS $>$ NZn $>$ control. Result revealed that grain yield in N, NP, NPK and NPK+FYM were statistically similar. Again grain yield in N, NP, NK, and NS were also statistically similar. Grain yield of boro rice was increased by $71 \%, 119 \%, 127 \%, 132 \%, 133 \%, 144 \%, 161 \%$ and $200 \%$ over Control in NZn, NS, NK, N, NP, NPK+FYM, NPK, NSZn and NPKSZn treatments respectively (Figure 1).

Statistical similarities were also found in NS, NSZn, NZn as well as NP, NPKS and NPK+FYM treatment.Like the grain yields, the straw yields of boro rice also varied remarkably due to different treatment combinations (Table 4). The yield varied from $2.63 \mathrm{t} \mathrm{ha}^{-1}$ in control and 5.34t ha ${ }^{-1}$ in NPKSZn treatment. Result revealed that straw yield in NS and NPKSZntreatments were statistically similar as well as NS, NSZn and NK, NPK, NZn, NPK+FYM and N, NP, NZn, NPK+FYM were statistically similar. Straw yield was increased by $82 \%, 83 \%, 98 \%, 110 \%, 112 \%, 139 \%, 145 \%$ and $167 \%$ over Control in N, NP, NPK+FYM, NZn, NK, NPK, NSZn, NS and NPKSZntreatments respectively (Figure 2).

\subsection{Effect of long-term mineral fertilization and manuring on yield and yield contributing characters of aman rice}

The plant height of aman rice (BR 11) in the experimental plot was significantly influenced due to different treatment combinations (Table 5). The highest plant height $(98.43 \mathrm{~cm})$ was recorded in NS treatment. Result revealed that plant height in NS, NSZn and NPKSZn were statistically similar. Plant height in control, N, NP, NK, NPK, NZn and NPK+FYM was also statistically similar. The lowest plant height $(86.17 \mathrm{~cm})$ was recorded in NPK+FYM treatment. Thousand grain weight $(\mathrm{g})$ analysis of variance of data showed that the effects of different treatment on 1000-grain weight (g) were not statistically significant (Table 5). The 1000-grain weight ranged from 23.13 to $24.37 \mathrm{~g}$. The 1000-grain weight followed the order of NK>NSZn> 
$\mathrm{NPK}=\mathrm{NPK}+\mathrm{FYM}>\mathrm{NS}=\mathrm{NPKSZn}>\mathrm{N}>\mathrm{NP}=\mathrm{NZn}>$ Control (Table 5).Counting the filled grains per panicle a remarkable variation was observed between the treatments (Table 5). The highest number of filled grains (130) was found in NS treatment, whereas the lowest number (105) was in N treatment. Result revealed that filled grain panicle ${ }^{-1}$ in NS, NSZn, NPKSZn as well as control, N, NP, NK, NPK, NZn, NPK+FYM were statistically similar. Counting the unfilled grains per panicle a remarkable variation was observed between the treatments (Table 5). The highest number of unfilled grains (16) was found in NPKSZn treatment, whereas the lowest number (13) was in $N$ treatment. Unfilled grain panicle ${ }^{-1}$ was found statistically similar in NSZn and NPKSZn as well as control, N, NP, NK, NPK, NS, NZn, $\mathrm{NPK}+\mathrm{FYM}$ treatments.It is evident from Table 5 that the number of tiller hill ${ }^{-1}$ was significantly affected by various treatment combinations (Table 5). The highest number of effective tiller hill ${ }^{-1}$ (9.00) was observed in NK whereas the lowest (6.00) was recorded in control. The plants hill ${ }^{-1}$ due todifferent treatments ranked in the order of $\mathrm{NK}>\mathrm{NS}=\mathrm{NSZn}=\mathrm{NPKSZn}>\mathrm{NPK}+\mathrm{FYM}>\mathrm{NP}=\mathrm{NPK}=\mathrm{NZn}>\mathrm{N}>\mathrm{Control}\left(\right.$ Table 5).The tiller hill ${ }^{-1}$ was statistically similar in NK, NS, NSZn and NPKSZn treatments. Results showed that tiller hill ${ }^{-1}$ was also statistically similar in Control, N, NP, NPK, NZn and NPK+FYM treatments.

There was also a significant effect of treatments on non-effective tiller. Non-effective tiller ranges between 0 in control, N, NP treatments and 1.00 in NK treatment. The number of non-effective tiller in control, N and NP as well as NPK, NS, NSZn, NPKSZn and NZn were statistically similar.

Like the grain yields, the straw yields of aman rice also varied remarkably due to different treatment combinations (Table 5). The yield varied from $4.36 \mathrm{tha}^{-1}$ in control to $6.91 \mathrm{t} \mathrm{ha}^{-1}$ in NS treatment. Result showed that straw yield in NK, NPK, NZn, NPK+FYM were statistically similar. On the other hand, straw yield in Control, N, NP, NPK were also found statistically similar. Straw yield was increased by $119 \%, 121 \%, 135 \%$, $142 \%, 149 \%, 152 \%, 200 \%, 217 \%$, and $246 \%$ over Control in NP, N, NPK, NPK+FYM, NK, NZn, NPKSZn, NSZn and NS treatments, respectively (Figure 4).

Table 1. Morphological characteristics of the permanent experimental fields.

\begin{tabular}{ll}
\hline Location & : Soil Science Field Laboratory, Bangladesh \\
& Agricultural University \\
Agro-ecological zone ( AEZ) & $:$ Old Brahmaputra Floodplain soils \\
Land type & $:$ High land \\
Parent material & $:$ Old Brahmaputra river borne alluvial deposits \\
General soil type & $:$ Non-calcareous Dark Grey Floodplain \\
Soil series & $:$ Sonatola \\
Topography & $:$ Fairly level \\
Flood level & $:$ Above normal flood level \\
Drainage & $:$ Poor \\
Consistency & $:$ Friable when moist \\
Vegetation & $:$ Mainly rice \\
\hline
\end{tabular}

Source: Soil survey report BAU farm Mymensingh (1978)

Table 2. Textural class and chemical characteristic of the permanent experimental fields.

\begin{tabular}{|c|c|}
\hline Characteristics & Value \\
\hline \multicolumn{2}{|l|}{ Particle size distribution } \\
\hline a. $\quad \%$ Sand $(2-0.02 \mathrm{~mm})$ & 11.65 \\
\hline$\%$ Silt $(0.02-0.002 \mathrm{~mm})$ & 75.70 \\
\hline c. $\quad$ \%Clay $(<0.002 \mathrm{~mm})$ & 12.65 \\
\hline Textural class & Silt loam \\
\hline $\mathrm{pH}$ & 6.92 \\
\hline Organic matter $(\%)$ & 2.82 \\
\hline Total Nitrogen $(\%)$ & 0.12 \\
\hline Available Phosphorus $\left(\left(\mathrm{mg} \mathrm{kg}^{-\mathrm{I}}\right)\right.$ & 12.6 \\
\hline Exchangeable Potassium (meq $100 \mathrm{~g}^{-1}$ soil) & 0.16 \\
\hline Available $\mathrm{Ca}\left(\mathrm{meq} 100 \mathrm{~g}^{-1}\right.$ soil $)$ & 9.43 \\
\hline Available $\mathrm{Mg}\left(\mathrm{meq} 100 \mathrm{~g}^{-1}\right.$ soil $)$ & 2.72 \\
\hline Available $\mathrm{S}\left(\mathrm{mg} \mathrm{kg}^{-1}\right)$ & 15.6 \\
\hline
\end{tabular}


Table 3. The doses and sources of different nutrients and FYM.

\begin{tabular}{llll}
\hline \multirow{2}{*}{ Nutrient Element } & \multicolumn{2}{c}{ Dose $\left(\mathbf{K g ~ h a}^{\mathbf{- 1})}\right.$} & Source (Fertilizers) \\
\cline { 2 - 4 } & Boro rice & Aman rice & \\
\hline $\mathrm{N}$ & 90 & 80 & Urea \\
$\mathrm{P}$ & 20 & 20 & TSP \\
$\mathrm{K}$ & 19 & 19 & MP \\
$\mathrm{S}$ & 30 & 30 & Gypsum \\
Zn & 5 & 5 & Zinc Oxide \\
FYM & 5000 & - & Decomposed cowdung \\
\hline
\end{tabular}

Table 4. Yield and yield contributing characters of boro rice.

\begin{tabular}{|c|c|c|c|c|c|c|c|c|c|c|c|}
\hline Treatments & PHT & PL & TGW & FG & UFG & ET & NET & GY & SY & BY & HI \\
\hline Control & $67.48 \mathrm{~d}$ & $21.50 \mathrm{~d}$ & 21.67 & $87.33 \mathrm{f}$ & $10.67 \mathrm{ef}$ & $6.00 \mathrm{e}$ & $0.330 \mathrm{~b}$ & $2.00 \mathrm{~g}$ & $2.63 \mathrm{e}$ & $4.63 \mathrm{f}$ & $43.23 \mathrm{~d}$ \\
\hline $\mathrm{N}$ & $72.70 b c$ & $23.68 \mathrm{a}$ & 22.67 & $96.67 \mathrm{~d}$ & $14.67 \mathrm{a}$ & $7.67 \mathrm{~cd}$ & $0.330 \mathrm{~b}$ & $4.63 \mathrm{cde}$ & $3.63 \mathrm{~d}$ & $.26 \mathrm{~d}$ & $56.06 \mathrm{a}$ \\
\hline NP & $73.63 \mathrm{ab}$ & $23.22 \mathrm{ab}$ & 23.00 & $110.0 \mathrm{a}$ & $11.67 \mathrm{de}$ & $7.33 \mathrm{~d}$ & $0.000 \mathrm{c}$ & $4.65 \mathrm{cde}$ & $3.65 d$ & $8.30 \mathrm{~d}$ & $56.09 \mathrm{a}$ \\
\hline NK & $70.83 \mathrm{bc}$ & $21.60 \mathrm{~d}$ & 21.33 & $93.33 \mathrm{de}$ & $14.33 \mathrm{a}$ & $7.33 \mathrm{~d}$ & $0.327 \mathrm{~b}$ & $4.53 \mathrm{de}$ & $4.19 \mathrm{c}$ & $.73 \mathrm{~cd}$ & $51.92 \mathrm{~b}$ \\
\hline NPK & $72.03 \mathrm{bc}$ & $21.96 \mathrm{~cd}$ & 24.33 & $91.33 \mathrm{e}$ & & $7.67 \mathrm{~cd}$ & $30 \mathrm{~b}$ & $4.88 \mathrm{c}$ & $4.24 \mathrm{c}$ & $11 \mathrm{c}$ & $53.58 \mathrm{ab}$ \\
\hline NS & & 23.2 & 23.00 & 105. & bcd & 8.33 & & 4.3 & $4.89 \mathrm{ab}$ & $9.26 \mathrm{c}$ & $19 \mathrm{c}$ \\
\hline NSZn & $70.90 \mathrm{bc}$ & $21.39 \mathrm{~d}$ & 22.67 & $93.67 \mathrm{de}$ & $13.67 \mathrm{ab}$ & $8.33 a b c$ & $0.330 \mathrm{~b}$ & $5.22 \mathrm{~b}$ & $4.78 \mathrm{~b}$ & $10.00 \mathrm{~b}$ & $52.21 \mathrm{~b}$ \\
\hline NPKSZn & $75.97 \mathrm{a}$ & $22.09 \mathrm{~cd}$ & 25.67 & $105.7 \mathrm{~b}$ & $12.00 \mathrm{~cd}$ & $9.00 \mathrm{a}$ & $0.670 \mathrm{a}$ & $5.99 \mathrm{a}$ & $5.34 \mathrm{a}$ & $11.33 \mathrm{a}$ & $52.89 \mathrm{ab}$ \\
\hline $\mathrm{NZn}$ & $69.37 \mathrm{~cd}$ & $22.95 \mathrm{abc}$ & 20.67 & $101.3 \mathrm{c}$ & $13.00 \mathrm{bc}$ & $8.00 \mathrm{bcd}$ & $0.327 \mathrm{~b}$ & $3.42 \mathrm{f}$ & $3.96 \mathrm{~cd}$ & $7.37 \mathrm{e}$ & $46.27 \mathrm{~cd}$ \\
\hline NPK+FYM & $70.60 \mathrm{bcd}$ & $22.07 \mathrm{bcd}$ & 21.00 & $103.7 \mathrm{bc}$ & $11.67 \mathrm{cde}$ & $8.67 \mathrm{ab}$ & $0.327 \mathrm{~b}$ & $4.87 \mathrm{~cd}$ & $3.95 \mathrm{~cd}$ & $8.82 \mathrm{~cd}$ & $55.23 \mathrm{ab}$ \\
\hline $\mathrm{LSD}_{0.05}$ & 3.08 & 1.07 & 3.58 & 3.91 & 1.23 & 0.863 & 0.076 & 0.312 & 0.457 & 0.539 & 3.29 \\
\hline $\mathrm{SE}( \pm)$ & 1.04 & 0.362 & 1.21 & 1.32 & 0.414 & 0.290 & & 0.105 & 0.154 & 0.182 & 1.11 \\
\hline & $* *$ & $* *$ & NS & $* *$ & $* *$ & $* *$ & $* *$ & $* *$ & $* *$ & $* *$ & $* *$ \\
\hline CV (\%) & 2.51 & 2.80 & 9.24 & 2.31 & 5.76 & 6.42 & 13.28 & 4.09 & 6.47 & 3.67 & 3.73 \\
\hline
\end{tabular}

Here, PHT- Plant height $(\mathrm{cm})$, PL- Panicle length $(\mathrm{cm})$, TGW-1000-grain weight $(\mathrm{g})$, FG- Filled grain panicle ${ }^{-1}$, UFGUnfilled grain panicle $e^{-1}$, ET- Effective tiller hill ${ }^{-1}$, NET- Non-effective tiller hill ${ }^{-1}$, GY- Grain yield $\left(\mathrm{t} \mathrm{ha}^{-1}\right)$, SY- Straw yield $\left(\mathrm{t} \mathrm{ha}^{-1}\right)$, BY- Biological yield $\left(\mathrm{t} \mathrm{ha}^{-1}\right)$ and HI- Harvest index $(\%)$

$* *=$ Significant at $1 \%$ level of probability, ${ }^{*}=$ Significant at $5 \%$ level of probability, NS $=$ Not significant

Table 5. Yield and yield contributing characters of aman rice.

\begin{tabular}{|c|c|c|c|c|c|c|c|c|c|c|c|}
\hline Treatments & PHT & PL & TGW & FG & UFG & ET & NET & GY & SY & BY & HI \\
\hline Control & $86.87 \mathrm{~cd}$ & $23.13 \mathrm{c}$ & 23.13 & $106.30 \mathrm{bc}$ & $15.00 \mathrm{~b}$ & $6.67 \mathrm{c}$ & $0.00 \mathrm{~d}$ & $3.02 \mathrm{~d}$ & $4.36 \mathrm{e}$ & $7.37 \mathrm{f}$ & $40.92 \mathrm{c}$ \\
\hline $\mathrm{N}$ & $7.20 \mathrm{~cd}$ & $23.30 \mathrm{bc}$ & 23.53 & $105.30 \mathrm{c}$ & $13.33 \mathrm{c}$ & $7.00 \mathrm{c}$ & $0.00 \mathrm{~d}$ & $3.73 \mathrm{c}$ & $4.41 \mathrm{e}$ & $8.14 \mathrm{de}$ & $45.79 \mathrm{a}$ \\
\hline NP & $\mathrm{cd}$ & $23.73 \mathrm{abc}$ & 23.43 & $111.30 \mathrm{bc}$ & $14.67 \mathrm{~b}$ & $7.67 \mathrm{bc}$ & $0.00 \mathrm{~d}$ & $3.57 \mathrm{c}$ & $4.38 \mathrm{e}$ & & $44.94 \mathrm{ab}$ \\
\hline NK & $92.33 \mathrm{bc}$ & $24.40 \mathrm{abc}$ & 24.37 & $114.70 \mathrm{~b}$ & $14.67 \mathrm{~b}$ & $9.67 \mathrm{a}$ & $1.00 \mathrm{a}$ & $4.31 \mathrm{~b}$ & $4.98 \mathrm{~d}$ & $9.29 \mathrm{c}$ & $46.40 \mathrm{a}$ \\
\hline NPK & $\mathrm{cd}$ & $23.90 \mathrm{abc}$ & 23.90 & 113. & $14.33 \mathrm{bc}$ & $7 \mathrm{bc}$ & $0.33 \mathrm{c}$ & $3.94 \mathrm{bc}$ & $4.70 \mathrm{de}$ & 4 cde & $45.57 \mathrm{a}$ \\
\hline NS & $3 \mathrm{a}$ & $25.03 \mathrm{a}$ & 23.63 & $130.30 \mathrm{a}$ & $15.00 \mathrm{~b}$ & $9.33 \mathrm{a}$ & $0.33 \mathrm{c}$ & $5.17 \mathrm{a}$ & $6.91 \mathrm{a}$ & $12.08 \mathrm{a}$ & $42.76 \mathrm{bc}$ \\
\hline NSZn & $a b$ & $24.60 \mathrm{abc}$ & 24.17 & $126.00 \mathrm{a}$ & $15.33 \mathrm{ab}$ & $9.33 \mathrm{a}$ & $0.33 \mathrm{c}$ & & $6.33 \mathrm{~b}$ & $8 \mathrm{~b}$ & $40.63 \mathrm{c}$ \\
\hline NPKSZn & 96.9 & $24.70 \mathrm{ab}$ & 23.63 & & $16.33 \mathrm{a}$ & 9.33 & $3 \mathrm{c}$ & & $5.99 \mathrm{c}$ & $8 \mathrm{~b}$ & $46.89 \mathrm{a}$ \\
\hline $\mathrm{NZn}$ & $0 \mathrm{~cd}$ & $23.43 \mathrm{bc}$ & 23.43 & & $14.00 \mathrm{bc}$ & $7.67 \mathrm{bc}$ & $0.33 \mathrm{c}$ & & $5.03 \mathrm{~d}$ & 8.7 & $42.22 \mathrm{bc}$ \\
\hline NPK+FYM & $86.17 \mathrm{~d}$ & $23.13 \mathrm{c}$ & 23.90 & $113.00 \mathrm{bc}$ & $14.33 \mathrm{bc}$ & 8.3 & $0.67 \mathrm{~b}$ & $3.94 \mathrm{bc}$ & $4.83 \mathrm{~d}$ & $8 \mathrm{~cd}$ & $44.93 \mathrm{ab}$ \\
\hline $\mathrm{LSD}_{0.05}$ & 4.93 & 1.32 & 0.981 & 8.25 & 1.18 & 0.916 & 0.076 & 0.476 & 0.339 & 595 & 2.58 \\
\hline $\mathrm{SE}( \pm)$ & 1.66 & 0.445 & 0.330 & 2.78 & 0.396 & 0308 & 0.023 & 0.160 & 0.115 & 0.234 & 0.869 \\
\hline Sig. level & $* *$ & $*$ & NS & $* *$ & ** & $* *$ & $* *$ & $* *$ & $* *$ & $* *$ & $* *$ \\
\hline $\mathrm{CV}(\%)$ & 3.16 & 3.22 & 2.41 & 4.15 & 4.67 & 6.46 & 12.10 & 6.77 & 3.82 & 4.36 & 3.41 \\
\hline
\end{tabular}

Here, PHT- Plant height $(\mathrm{cm})$, PL- Panicle length $(\mathrm{cm})$, TGW-1000-grain weight $(\mathrm{g})$, FG- Filled grain panicle ${ }^{-1}$, UFGUnfilled grain panicle ${ }^{-1}$, ET- Effective tiller hill ${ }^{-1}$, NET- Non-effective tiller hill ${ }^{-1}$, GY- Grain yield $\left(\mathrm{t} \mathrm{ha}^{-1}\right)$, SY- Straw yield $\left(\mathrm{t} \mathrm{ha}^{-1}\right)$, BY- Biological yield $\left(\mathrm{t} \mathrm{ha}^{-1}\right)$ and HI- Harvest index $(\%)$

$* *=$ Significant at $1 \%$ level of probability

$*=$ Significant at $5 \%$ level of probability

NS $=$ Not significant 


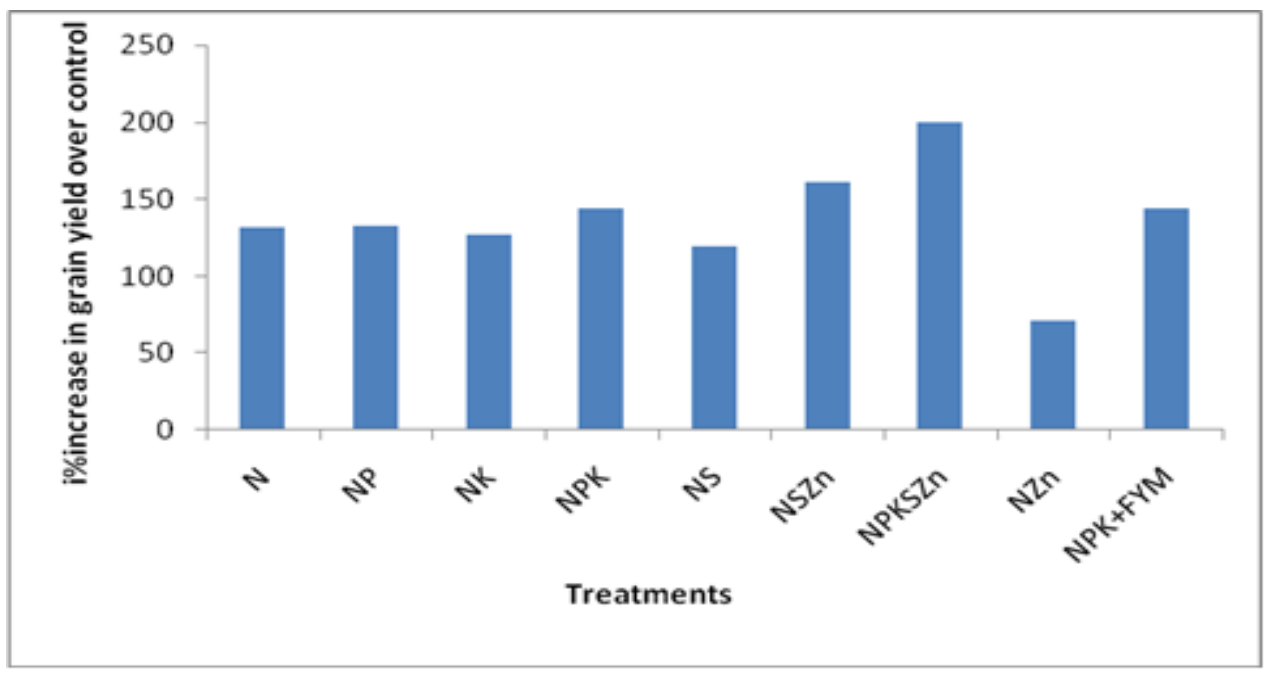

Figure 1. Effects of different fertilizers and manures on $\%$ increase of grain yield of boro rice over control.

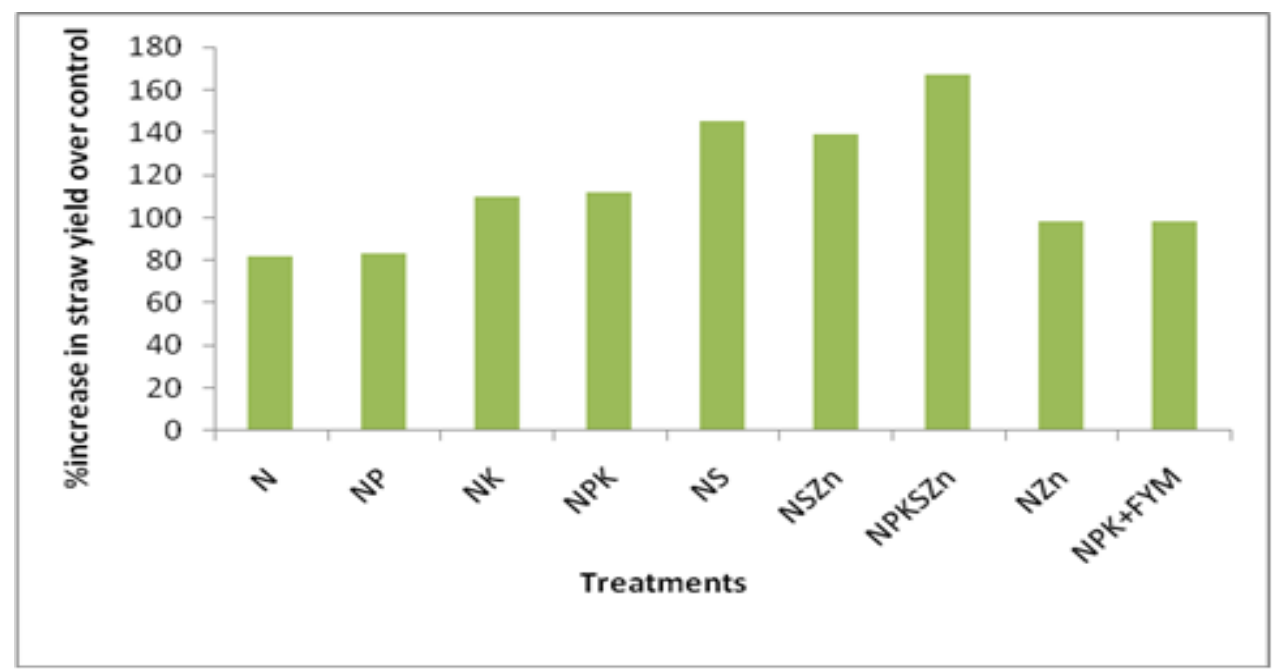

Figure 2. Effects of different fertilizers and manures on \% increase of straw yield of boro rice.

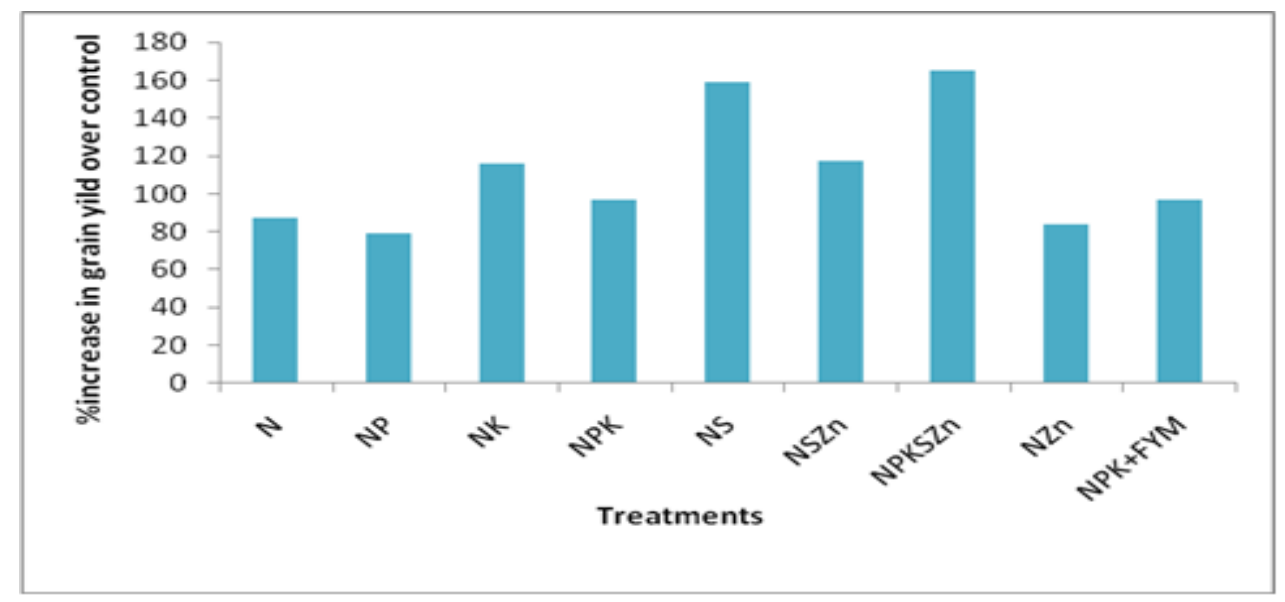

Figure 3. Effects of different fertilizers and manures on \% increase of grain yield of aman rice over control. 


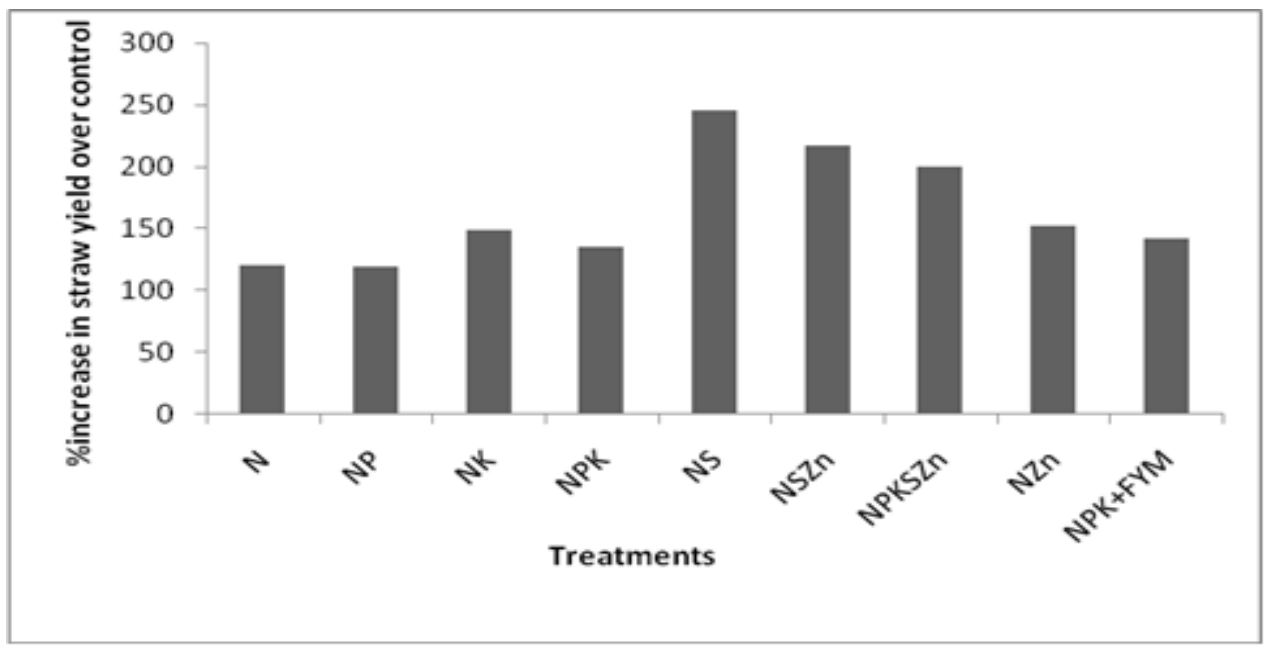

Figure 4. Effects of different fertilizers and manures on \% increase of straw yield of aman rice over control.

\section{Discussion}

The long term effect of different fertilization and manuring significantly influenced the yield and yield contributing characters of boro rice.The highest values of plant height $(75.97 \mathrm{~cm}), 1000$-grain weight $(25.67 \mathrm{~g})$, effective tiller hill' ${ }^{-1}(9)$, grain yield $\left(5.99 \mathrm{tha}^{-1}\right)$, straw yield $\left(5.34 \mathrm{t} \mathrm{ha}^{-1}\right)$ and biological yield $\left(11.33 \mathrm{t} \mathrm{ha}^{-1}\right)$ were observed in NPKSZn treatment. The highest value of panicle length $(23.68 \mathrm{~cm})$ was got from $\mathrm{N}$ treatment; the highest values of filled grain panicle ${ }^{-1}(110)$ and harvest index $(56.09 \%)$ were recorded from NP treatment. The highest value of unfilled grain (14.33) was recorded in NK treatment. Thus the result showed that most yield and yield components of boro ricewere increased with the application of NPKSZn treatment. From the present study, it was also observed that the different fertilization and manuring had a significant effect on the yield and yield components of aman rice. The higher values of yield parameters and yields were recorded in the treatments where fertilizer plus manure were used. The highest value of plant height $(98.43 \mathrm{~cm})$, panicle length $(25.03 \mathrm{~cm})$, filled grain panicle ${ }^{-1}(130)$, straw yield $\left(6.91 \mathrm{t} \mathrm{ha}^{-1}\right)$ and biological yield $\left(12.08 \mathrm{t} \mathrm{ha}^{-1}\right)$ were found from NS treatment. The highest values of 1000 -grain weight $(24.37 \mathrm{~g})$, effective tiller hill ${ }^{-1}(9.67)$ were recorded in NK treatment. However, the highest grain yield $\left(5.29 \mathrm{tha}^{-1}\right)$ and harvest index (46.89\%) were found from NPKSZn treatment.

These results are similar to Wang et al. (2004) and Chalk et al. (2003) who found that in most long-term experiments, a combination of mineral fertilizers and farmyard manures has generally given the best crop yield and soil quality. The results are also supported by Rasool et al. (2007) who concluded that application of manure and an inorganic fertilizer in rice- heat cropping system, increased paddy yield in rice because manure application improves soil health and provides plant nutrients (Bhattacharyya et al., 2010).

\section{Conclusions}

Cropping patterns in Bangladesh are mainly rice-based. In most of the cases, farmers use only $\mathrm{N}$ fertilizer alone or $\mathrm{N}$ and $\mathrm{P}$ fertilizer or at best $\mathrm{N}, \mathrm{P}$, and K fertilizers combinedly. The nutrient elements namely $\mathrm{S}$ and $\mathrm{Zn}$ are found as deficient in Bangladeshi paddy soils. In addition, only use of chemical fertilizer is not judicious for producing any crop. Integrated use of chemical fertilizers and organic manure is necessary for crop production as well as maintaining soil fertility. Generally, soil productivity and health may be more sustainable with the integrated application of manure and inorganic fertilizers than that of only use of inorganic fertilizers alone. The findings of this experiment revealed that the recommended dose of NPKSZn gave the best yield in both boro and aman season.

\section{Acknowledgements}

The principal author, Bornali Mostofa along with others is thankful to the Ministry of Science and Technology, Bangladesh; Department of Soil Science, Bangladesh Agricultural University for their technical assistance.

\section{Conflict of interest}

None to declare. 


\section{References}

BBS (Bangladesh Bureau of Statistics), 2011. Monthly Statistical Bulletin of Bangladesh, Statistical Division, Ministry of Planning, Government People's Republic of Bangladesh, Dhaka. pp. 52-56.

BBS (Bangladesh Bureau of statistics), 2012. Planning Division, Ministry of Planning, Government of Peoples Republic of Bangladesh, Dhaka. p. 83.

Ranjan B, S Kundu, V Prakash and HS Gupta, 2008. Sustainability under combined application of mineral and organic fertilizers in a rainfed soybean-wheat system of the Indian Himalyas. European Journal of Agronomy, 28: 33-46.

Ranjan B, V Prakash, S Kundu, AK Srivastva, HS Gupta and S Mitra, 2010. Long term effects of fertilization on carbon and nitrogen sequestration and aggregate associated carbon and nitrogen in the Indian Himalayas. Nutrient Cycling in Agroecosystem, 86: 1-16.

FAO, 2014. Global network on integrated soil management for sustainable use of salt-affected soils. Food and Agriculture Organisation, Rome, Italy.

Ahmed H, MJ Abedin Mian and MA Hossain, 2009. Effect of Long-Term Mineral Fertilization and Manuring on Soil Properties, Yield and Nutrient Uptake by T-aman Rice. Bangladesh Res. Pub. J., 3:774-786.

Hasan MM, 2007. Effect of long-term application of manures and fertilizers on soil properties, yield and nutrient uptake by T-aman rice. MS thesis, Department of Soil Science, Bangladesh Agricultural University, Mymensingh.

Katyal JC, NH Rao and MN Reddy, 2001. Critical aspects of organic matter management in the tropics: the examples of India. Nutrient Cycling in Agroecosystem, 61: 77-88.

Rasool R, SS Kakul and GS Hira, 2007. Soil physical fertility and crop performance as affected by long term application of FYM and inorganic fertilizers in rice-wheat cropping system. Soil and Tillage Research, 96: 64-72.

Vineela C, SP Wani, C Srinivasrao, B Padmaja and KPR Vittal, 2008. Microbial properties of soils as affected by cropping and nutrient management practices in several long-term manorial experiments in the semi-arid tropics of India. Applied Soil Ecology, 40: 165-73.

Wang KR, X Liu, WJ Zhou, XL Xie and RJ Buresh, 2004. Effects of nutrient recycling on soil fertility and sustainable rice production. J. Agro-Env. Sci., 23:1041-1045. 